\title{
Optimalization of recovery, regeneration and rehabilitation
}

\author{
Jaroslav Novak1, Václav Zeman ${ }^{*}$, Martin Matoulek², Ondřej Topolčan', Śárka Svobodova², Jaroslav Racek, \\ Judita Kinkorova ${ }^{3}$ \\ From EPMA-World Congress 2013 \\ Brussels, Belgium. 20-21 September 2013
}

\section{Scientific objectives}

Physically active subjects have superior aerobic performance and effort tolerance compared to the less active subjects. There was observed association between high exercise capacity and low mortality. The protective effect of physical activity and exercise capacity preventing the progression of diseases, and thus on premature death, could be one of explanations for this association. Most of this protection is assumed to result from the beneficial effects of physical exercise on blood lipids, blood pressure, glucose metabolism, vascular function, autonomic tone, blood coagulation, and inflammation.

\section{Technological approaches and results interpretation}

We have currently initiated the examination of metabolic parameters, hormones, inflammatory parameters, growth angiogenic parameters and bone metabolism parameters in 4 groups of individuals: active sportsmen, sportsmen involved in sports with extreme load (i.e. ultra-marathon performance - e.g. $100 \mathrm{~km}$ running in $24 \mathrm{hrs}$, intermediate and long triathlons, long-distance swimming, etc.), in patients with cancer diseases and patients with cardiovascular diseases, who were individually recommended appropriate form of physical activity as a part of complex therapy.

\section{Outlook and expert recommendations}

The aim of this study was to compare the differences of the monitored parameter between the different groups of patients that are significantly different from health condition and from the level of physical activity. The

\footnotetext{
* Correspondence: Vaclav.Zeman@lfp.cuni.cz

${ }^{1}$ Medical Faculty Pilsen and Faculty Hospital Pilsen, Charles University Prague, Czech Republic

Full list of author information is available at the end of the article
}

final goal is to find the optimal biomarkers potentially useful as an indicator of optimal recovery course and rehabilitation after physical activity load - single evaluation and long term monitoring.

\section{Acknowledgements \\ This study was supported by the project Ministry of Education ED2.1.00/ 03.0040 and by the project of Ministry of Health, Czech Republic for conceptual development of research organization 00669806 - Faculty Hospital in Pilsen, Czech Republic.}

\section{Authors' details}

${ }^{1}$ Medical Faculty Pilsen and Faculty Hospital Pilsen, Charles University Prague, Czech Republic. ${ }^{2} 1^{\text {st }}$ Medical Faculty Prague and General Faculty Hospital Prague, Charles University, Prague, Czech Republic. ${ }^{3}$ Technology Centre Academy of Sciences, Czech Republic.

Published: 11 February 2014

\section{doi:10.1186/1878-5085-5-S1-A152}

Cite this article as: Novak et al:: Optimalization of recovery,

regeneration and rehabilitation. EPMA Journal 2014 5(Suppl 1):A152.

Submit your next manuscript to BioMed Central and take full advantage of:

- Convenient online submission

- Thorough peer review

- No space constraints or color figure charges

- Immediate publication on acceptance

- Inclusion in PubMed, CAS, Scopus and Google Scholar

- Research which is freely available for redistribution

Submit your manuscript at www.biomedcentral.com/submit
() Biomed Central 